Creative Commons User License: CC BY-NC-ND

Abstracted by: EBSCOhost, Electronic Journals Service (EJS),

Google Scholar, Journal Seek, Scientific Commons,

Food and Agricultural Organization (FAO), CABI and Scopus
Journal of Agricultural Extension

Vol. 24 (1) January, 2020

ISSN(e): 24086851; ISSN(Print); 1119944X

http://journal.aesonnigeria.org

http://www.ajol.info/index.php/jae

Email: editorinchief@aesonnigeria.org

\title{
Scriptwriters' Perception of Use of Soap Opera in Agricultural Information Dissemination in South-western Nigeria \\ https://dx.doi.org/10.4314/jae.v24i1.6
}

\section{Olajide, Bamidele. $\mathbf{R}$.}

Department of Agricultural Extension and Rural Development,

Faculty of Agriculture and Forestry, University of Ibadan, Ibadan.

E-mail: r.olajide@gmail.com., Phone: +2348034077794.

\section{Ladigbolu, Temitope. A.}

Department of Agricultural Extension and Rural Development,

Faculty of Agriculture and Forestry, University of Ibadan, Ibadan.

E-mail: adejojutemitope@gmail.com., Phone: +2348035337569.

Abstract

The study assessed scriptwriters' perception of use of soap opera for agricultural information dissemination in South-western Nigeria. A total of 30 scriptwriters were interviewed using questionnaire Data were analysed using frequencies, percentages, means, Pearson Product Moment Correlation $(P P M C)$ and linear regression at $p=0.05$. Findings reveal that lack of adequate fund (243.4) and lack of sponsors (226.6) were perceived constraints by scriptwriters to developing scripts for promoting agriculture using soap opera. The majority (93.3\%) had favourable perception of the use of soap opera for promoting agriculture. There was a significant relationship between perceived constraints $(r=0.12 ; p \leq 0.05)$ and scriptwriters' perception of use of soaps for promoting agriculture, while age $(\beta=3.18, t=12.05, p=$ $\leq 0.05)$ and being an actor $(\beta=1.96, t=7.61, p=\leq 0.05)$ were the main determinants of scriptwriters' perception of use of soap opera in dissemination of agricultural information. Scriptwriters' favourable perception is a green light for production of agricultural based soap in Nigeria if sponsorship is guaranteed. It is recommended that an adequate source of fund or sponsorship should be sourced for use of soap opera for agricultural information dissemination.

Keywords: Scriptwriters, agricultural information, soap opera Introduction

In Nigeria, like other developing countries of the world, the importance of information transfer to small scale farmers is paramount. Information to equip farmers on every aspect of life in order to increase their knowledge for improved agricultural productivity is highly desired. Some of this information needed include import and export duties, promoting environmentally sustainable production techniques, and coping with the effects of HIV/AIDS and other health challenges that affect agriculture, improved varieties, cropping techniques, optimal input use, prices and market conditions, more efficient methods of production and management, storage and nutrition among others. According to Ali and Ahmadu (2014), means of information transfer in our society is through mass media which can be any of audio, audio-visual, print media, and recently internet (radio, television, magazines, journals and newspaper). There are several methods that have been used all over the world, Nigeria inclusive to transfer information to the target audience, by agricultural 
Creative Commons User License: CC BY-NC-ND

Abstracted by: EBSCOhost, Electronic Journals Service (EJS), Google Scholar, Journal Seek, Scientific Commons,

Food and Agricultural Organization (FAO), CABI and Scopus
Journal of Agricultural Extension

Vol. 24 (1) January, 2020

ISSN(e): 24086851; ISSN(Print); 1119944X

http://journal.aesonnigeria.org

http://www.ajol.info/index.php/jae

Email: editorinchief@aesonnigeria.org

extension agents. Some of these methods or media employed for agricultural information dissemination include personal contact, radio broadcasts, television broadcasts, publications (extension publications), field days, agricultural shows, demonstrations, while deploying different formats for each method employed. One of such potent format is drama format because of its ability to appeal to almost all sense organs of the target audience among other benefits.

Drama-formats are popularly expressed in mass media production as soap operas. Soap opera is a serial drama format that can be presented both on radio and television in continuous episodes (Alessandro and Cacilda, 2018). Soap opera started in the United States in the early 1930s. It started on radio with short and domestic dramas (Allen, 2014). According to Kevill, and Connock, (2013), soap opera gained its name after soap manufacturing companies that sponsored the content, was launched in the 1930s and since the inception of the soap opera, they constitute one of the most striking features of the history of commercial broadcast programming. Literature has shown that viewers acquire attitudes, emotional responses and new styles of conduct from media, especially from films and television (Bandura and Liebert, 1973, cited in Ullah, Ali, Nisar, Farid, Ali, \& Alam, 2014). Soap opera addresses issues of class, poverty, family drama, health, politics, economy, social and agricultural matters which carry certain cultural values that audiences can relate to. Some viewers often identify very closely with the lead soap characters. According to Semlali (2013), introduction of critical social issue into the soap narrative can go from being simply "entertainment" to being "entertainment-education".

Meanwhile, agricultural sector in Nigeria in the last 30 years is left out from the benefits of soap opera as little or none is known about agriculture-based soap opera. This might probably be because entertainment industry is mainly aiming at profit making or because of the general belief that agricultural and other development stories are not too entertaining (Sheila and Cody, 2015). To address this problem, script writing becomes pertinent. It is on this strength that it is envisage that if only the scriptwriters are favourably disposed to writing educative and entertaining story lines, the potential of soap opera for pushing development issues in general and agriculture in particular can be unleashed.

Therefore, in order to explore the potentials and possibilities of soap opera to strengthen agricultural extension delivery in Nigeria, it is important that scriptwriters' opinion and readiness to soap opera for promoting agriculture is ascertained. It is against that backdrop that this study examined scriptwriters' perception of use of soap opera in agricultural information management in South-western Nigeria. The specific objectives were to: identify personal and professional characteristics of scriptwriters; determine scriptwriters' perception of the use soap opera for promoting agriculture; identify scriptwriters' perceived constraints to developing scripts for soap opera to promote agriculture; and Ascertain significant relationship between scriptwriters' perceived constraints and their perception about the use of soap opera for promoting agriculture 
Creative Commons User License: CC BY-NC-ND

Abstracted by: EBSCOhost, Electronic Journals Service (EJS),

Google Scholar, Journal Seek, Scientific Commons,

Food and Agricultural Organization (FAO), CABI and Scopus
Journal of Agricultural Extension

Vol. 24 (1) January, 2020

ISSN(e): 24086851; ISSN(Print); 1119944X

http://journal.aesonnigeria.org

http://www.ajol.info/index.php/jae

Email: editorinchief@aesonnigeria.org

\section{Methodology}

This study was carried out in South-western zone of Nigeria. This comprises six states namely Lagos, Oyo, Ondo, Ogun, Osun, Delta, Edo and Ekiti states. The geographical location of Southwest zone of Nigeria lies between $6^{0} \mathrm{~N}$ and $9^{0} \mathrm{~N}$ latitude and approximately between $2^{\circ} \mathrm{E}$ and $7^{\circ} \mathrm{E}$ longitude. This area covers about $114,271 \mathrm{~km}^{2}$ It is bounded in the North by Kwara and Kogi states, in the East by River Niger, in the South by Atlantic Ocean and in the West by Republic of Benin.

A three-stage sampling procedure was used to select respondents. In the first stage, three states from the six states of southwest agricultural zone, Nigeria (Lagos, Ogun and Oyo states) were selected using purposive sampling technique. This was based on the fact that these three states are the hub of film production in southwest Nigeria; hence they house the highest percentage of scriptwriters, film directors and producers. Due to circumstance and nature of the professional callings of scriptwriters, members of the national and states' executive officers of Theatre Arts and Motion Pictures Producers Association of Nigeria (TAMPPAN) were purposively selected in the second stage. Across the national and states' executive members, there were 43 members of TAMPPAN and all were chosen and interviewed in the third stage. However, only 30 executive members returned completely filled and usable questionnaire. Data were collected using questionnaires and were analysed with percentages, the Pearson Product Moment Correlation (PPMC) and linear regression were used in data analysis.

Scriptwriters' perception was measured based on the five contingency factors (audience characteristics, organizational factors, media environment factors, programme specific factors and infrastructural factors) used by Olajide and Meroyi (2014). These factors determine effectiveness of an entertainment-education strategy. It was measured with a 20 perception statements on a three-point Likert type scale of "strongly agreed", "undecided" and "strongly disagreed". These were scored in a descending order of 3,2 and 1 for all positive statements and in the reverse order for all negative statements. Minimum obtainable perception score was 20 and maximum obtainable score was 60 . The mean value was used to determine the level of perception with respondents whose scores were below the mean value categorised as unfavourable perception, while respondents' scores that are equal to and above the mean value were categorised as favourable perception.

Scriptwriters' perceived constraints was measured by providing a list of factors that may be hindrance to developing a good script for soap to promote agriculture. They were asked to indicate order of severity from "not a constraint", "mild constraint" or "severe constraint" and scores of 0,1 and 2 were assigned, respectively. Minimum score was 0 while a maximum score obtainable was 22 .

Scriptwriters' personal characteristics such as age, marital status, sex, years of schooling, scriptwriters' cadre in the film industry and course of study were also measured at nominal, ordinal and interval level of measurement accordingly. 
Creative Commons User License: CC BY-NC-ND

Abstracted by: EBSCOhost, Electronic Journals Service (EJS),

Google Scholar, Journal Seek, Scientific Commons,

Food and Agricultural Organization (FAO), CABI and Scopus
Journal of Agricultural Extension

Vol. 24 (1) January, 2020

ISSN(e): 24086851; ISSN(Print); 1119944X

http://journal.aesonnigeria.org

http://www.ajol.info/index.php/jae

Email: editorinchief@aesonnigeria.org

\section{Results and Discussion}

\section{Professional Characteristics}

Table 1 shows that $40.0 \%$ of the scriptwriters indicated film producers, and $33.3 \%$ indicated actors as their cadre in the film industry. Only a few $(6.7 \%)$ studied theatre art, $13.3 \%$ studied cinematography, while $26.7 \%$ and $13.3 \%$ studied education and philosophy, respectively. This implies that majority of the scriptwriters do not have background training in theatre art or theatre art related courses. Although this might also affect their ability to develop good scripts for soap opera to promote agriculture, but it is also an avenue for graduate of agricultural extension graduates who might want to take to script writing or might be interested in acting and writing scripts for soap opera to promote agriculture. Meanwhile, according to de Fossard \& Lande (2018), an experienced writer is the better choice; experienced writers usually can create an appealing story, even on an unfamiliar subject.

Table 1: Scriptwriters professional characteristics

\begin{tabular}{|c|c|c|}
\hline Characteristics & Category & Percentage Mean \\
\hline \multirow[t]{5}{*}{ Cadre in the film industry } & Director & 6.7 \\
\hline & Producer & 40.0 \\
\hline & Scriptwriter & 13.3 \\
\hline & Actor & 33.3 \\
\hline & Movie analyst & 6.7 \\
\hline \multirow[t]{6}{*}{ Course of study } & Not applicable & 6.7 \\
\hline & $\begin{array}{l}\text { Business } \\
\text { administrative }\end{array}$ & 10.0 \\
\hline & Education & 26.7 \\
\hline & Cinematography & 13.3 \\
\hline & Philosophy & 13.3 \\
\hline & $\begin{array}{l}\text { Mass } \\
\text { communication }\end{array}$ & 23.3 \\
\hline
\end{tabular}

Source: Field survey, (2016)

\section{Scriptwriters' Perception of Use of Soap Opera in Agricultural Information Dissemination}

As indicated in Table 2, $100.0 \%$ of scriptwriters strongly agreed that soap opera could promote relevant agricultural related issues and farming activities. The same proportion (100.0\%) also strongly agreed that using soap opera to disseminate agricultural information would stimulate community discussion that will lead to the establishment of new values and norms. In addition, (100.0\%) equally agreed that farmers' cultural and religious background should not prevent them from obtaining agricultural information from soap opera. Also, a higher proportion (90.0\%) of the scriptwriters agreed also that soap opera should not be used to disseminate only 
Creative Commons User License: CC BY-NC-ND

Abstracted by: EBSCOhost, Electronic Journals Service (EJS), Google Scholar, Journal Seek, Scientific Commons,

Food and Agricultural Organization (FAO), CABI and Scopus

http://eoi.citefactor.org/10.11226/v23i4
Journal of Agricultural Extension

Vol. 24 (1) January, 2020

ISSN(e): 24086851; ISSN(Print); 1119944X

http://journal.aesonnigeria.org

http://www.ajol.info/index.php/jae

Email: editorinchief@aesonnigeria.org

agricultural information but useful information for farmers and rural dwellers generally, as well as the fact that.

The implication is that scriptwriters were of the opinion that using soap opera to disseminate agricultural information would stimulate community discussion that will lead to the establishment of new values and norms. In the same vein, higher proportion of them agreed that soap opera could promote relevant agricultural related issues and farming activities. Overall scriptwriters' disposition suggests a favourable perception as $93.3 \%$ had positive disposition to the use of soap opera for agricultural information management.

This implies that opinions of scriptwriters are in favour of the use of soap opera for agricultural information dissemination. This might not be in accordance with general belief that scriptwriters might just be after their remunerations. It is also not in tandem with popular position that agricultural stories are boring and not profitable unlike purely entertainment-based genre. This aligns with Sheila and Cody (2015) who upheld the general belief that agricultural and other development stories are not so entertaining. 
Creative Commons User License: CC BY-NC-ND

Abstracted by: EBSCOhost, Electronic Journals Service (EJS),

Google Scholar, Journal Seek, Scientific Commons,

Food and Agricultural Organization (FAO), CABI and Scopus
Journal of Agricultural Extension

Vol. 24 (1) January, 2020

ISSN(e): 24086851; ISSN(Print); 1119944X

http://journal.aesonnigeria.org

http://www.ajol.info/index.php/jae

Email: editorinchief@aesonnigeria.org

http://eoi.citefactor.org/10.11226/v23i4

Table 2: Scriptwriters perception of use of soap opera in agricultural information dissemination

\section{Statements}

Using soap opera to disseminate agricultural information would stimulate community discussion that will lead to the establishment of new values and norms

Soap opera could promote relevant agricultural related issues and farming activities

Soap opera should not be used to disseminate only agricultural information but useful information for farmers and rural dwellers generally

Farmers' cultural and religious background should not prevent them from obtaining agricultural information from soap opera.

Lack of sustained funding is likely to stall the use of soap opera for agricultural information management because agricultural soap opera is not generally patronized

Economic interest of prospective sponsors of soap opera for agricultural information management has to be prioritised

Agricultural and rural development experts need to be in charge of balancing the interest in soap opera to focus on agricultural information management

Reliability of sources of information on soap opera for agricultural information management will determine its effectiveness

Contentions in appropriateness of time for soap opera would affect its use for agricultural information management

Abundant talents in Nigerian actors can effectively appropriated for soap opera to pursue agricultural information management

Extension service agencies would be critical partners in the use of soap opera to promote agriculture

Sufficient infrastructures should be in place to aid script writing

Uninterrupted episodes of soap opera for agricultural information management is necessary for hammer the relevance of message delivered

The research requirement for execution of soap opera to promote agriculture lacking and this will rendered the use unachievable

Soap opera cannot be used to achieve any spectacular agricultural information management than what has been previously achieved

Soap opera will be very difficult to address certain agricultural information

Interest might conflicts when local language are used in soap opera for agricultural information management

Multi-disciplinary nature of agriculture will rather boost soap opera than promote agriculture

Repetition of soap opera episodes would not be desirable to reinforce messages being promoted by soap opera for information management

Infrastructure challenge is not real in case of soaps that promote agriculture

Overall level of favourable perception

Source: Field survey, (2016)

\section{$\%$ agreeing}

100.0

90.0

100.0

86.6

93.3

53.3

100.0

0.0

16.6

0.0 
Creative Commons User License: CC BY-NC-ND

Abstracted by: EBSCOhost, Electronic Journals Service (EJS), Google Scholar, Journal Seek, Scientific Commons,

Food and Agricultural Organization (FAO), CABI and Scopus
Journal of Agricultural Extension

Vol. 24 (1) January, 2020

ISSN(e): 24086851; ISSN(Print); 1119944X

http://journal.aesonnigeria.org

http://www.ajol.info/index.php/jae

Email: editorinchief@aesonnigeria.org

\section{Perceived Constraints in Writing Agriculture-Based Script for Soap Opera}

Table 3 reveals that scriptwriters' perceived constraints in order of magnitudes were: lack of adequate fund (243.4), unfavourable disposition of sponsors to agricultural message (230.2), lack of harmony among sponsors and agricultural extension agencies for direction for soap opera strategy (230.2), lack of sponsors (226.6) and lack of motivation or flair to write script for agricultural soap opera (203.3). This implies that quite a number of issues will need to be addressed to get good scripts for soap opera that will promote agricultural information.

The inference is that almost all the scriptwriters' perceived constraints are fundrelated and are on sponsorship. This buttresses the fact that sponsorship is germane to soap production. Olajide and Meroyi (2014) implicated similar constraints in a study that compares stakeholders' perception of the use of entertainment- education for agricultural information dissemination in South-western Nigeria. Meanwhile, Oh (2014) asserts that the British Broadcasting Corporation (BBC) informed that producing a movie in Nigeria costs an average $\$ 25,000-\$ 70,000$. Also, according to de Fossard \& Lande (2018), the cost of radio drama in 2001 in varies from $\$ 120,000$ in Albania and $\$ 150,000$ in Tanzania per year in Europe and Africa, respectively, while in Asia, North Indian to be precise, television production cost $\$ 2.2$ million in 2003. This portends that huge investment is required and the perceived constraints relating to funding and sponsorship as identified by the script writers are not fluke.

Table 5 indicates that scriptwriters' perceived constraints $(r=0.54 ; p \leq 0.01)$ was positively correlated with their perception about the use soap opera for promoting agriculture. This implies that scriptwriters' opinion about the use of soap opera for agricultural information is not in isolation of possible constraints of its deployment for agricultural information dissemination. It could also be taken that the perception might have been informed by the benefit of hindsight that soap use for agricultural information dissemination is plausible as long as the perceived constraints could be checked and eliminated. 
Creative Commons User License: CC BY-NC-ND

Abstracted by: EBSCOhost, Electronic Journals Service (EJS), Google Scholar, Journal Seek, Scientific Commons,

Food and Agricultural Organization (FAO), CABI and Scopus
Journal of Agricultural Extension

Vol. 24 (1) January, 2020

ISSN(e): 24086851; ISSN(Print); 1119944X

http://journal.aesonnigeria.org

http://www.ajol.info/index.php/jae

Email: editorinchief@aesonnigeria.org

http://eoi.citefactor.org/10.11226/v23i4

Table 3: Scriptwriters' perceived constraints in writing script for soap opera to promote agriculture

\begin{tabular}{|c|c|c|}
\hline Perceived constraints & $\begin{array}{l}\text { Weighted } \\
\text { score }\end{array}$ & Rank \\
\hline Lack of adequate funding & 243.4 & $1^{\text {st }}$ \\
\hline $\begin{array}{l}\text { Unfavourable disposition of sponsors to agricultural } \\
\text { message }\end{array}$ & 230.2 & $2^{\text {nd }}$ \\
\hline $\begin{array}{l}\text { Lack of harmony among sponsors and agricultural } \\
\text { extension agencies for direction for soap opera strategy }\end{array}$ & 230.2 & $3^{\text {rd }}$ \\
\hline Lack of sponsors & 226.6 & $4^{\text {th }}$ \\
\hline $\begin{array}{l}\text { Lack of motivation or flair to write script for agricultural } \\
\text { soap opera }\end{array}$ & 203.3 & $5^{\text {th }}$ \\
\hline $\begin{array}{l}\text { Insufficient agricultural information items on soap opera } \\
\text { to cover }\end{array}$ & 196.7 & $6^{\text {th }}$ \\
\hline Competing issues and areas of intervention & 186.7 & $7^{\text {th }}$ \\
\hline $\begin{array}{l}\text { Cumbersomeness of agricultural information required by } \\
\text { farmers }\end{array}$ & 166.7 & $8^{\text {th }}$ \\
\hline $\begin{array}{l}\text { Inability to adapting prospective audience's profile while } \\
\text { writing script for soap opera }\end{array}$ & 163.4 & $9^{\text {th }}$ \\
\hline $\begin{array}{l}\text { Inconsistent nature of the prospective audience } \\
\text { (famers) }\end{array}$ & 163.3 & $10^{\text {th }}$ \\
\hline $\begin{array}{l}\text { Difficulty in coming up with interesting story line for soap } \\
\text { opera to promote agriculture }\end{array}$ & 133.4 & $11^{\text {th }}$ \\
\hline
\end{tabular}

Source: Field survey, (2016)

Table 4: Relationship between scriptwriters' perceived constraints and perception of soap opera usability in agricultural information management

\begin{tabular}{ll}
\hline Variables & r- value \\
\hline Perception index * ${ }^{*}$ perceived constraints & 0.54
\end{tabular}

${ }^{*} \mathrm{P} \leq 0.05$. Source: Field survey, (2016)

Socio-Economic Factors Influencing Perception of Use of Soap Opera in Agricultural Information Dissemination

Table 5 reveals that certain respondents' characteristics significantly contributed to their perception of use of soap opera in agricultural information dissemination. These are scriptwriters' age $(\beta=3.18, t=12.05, p \leq 0.05)$, marital status $(\beta=-0.79, t=-$ $5.40, p \leq 0.05)$, being an actor $(\beta=1.96, t=7.61, p=\leq 0.05$, being a film analyst $(\beta=$ $2.91, t=8.49, p=\leq 0.05)$, being a scriptwriter $(\beta=1.41, t=5.77, p=\leq 0.05)$. Others are courses studied including business administration $(\beta=-0.46, t=-2.57, p \leq 0.050$ cinematography $(\beta=0.66, t=5.55, p \leq 0.05)$ and philosophy $(\beta=-2.14, t=-6.67, p$ $\leq 0.05)$. This implies that age, being married, being an actor, being a film analyst and being a scriptwriter, course studied including: business administration, cinematography and philosophy are all the factors that influenced scriptwriters' favourable perception of soap opera usability in agricultural information 
Creative Commons User License: CC BY-NC-ND

Abstracted by: EBSCOhost, Electronic Journals Service (EJS), Google Scholar, Journal Seek, Scientific Commons,

Food and Agricultural Organization (FAO), CABI and Scopus
Journal of Agricultural Extension

Vol. 24 (1) January, 2020

ISSN(e): 24086851; ISSN(Print); 1119944X

http://journal.aesonnigeria.org

http://www.ajol.info/index.php/jae

Email: editorinchief@aesonnigeria.org

dissemination. The fact that age, being married, being an actor, being a film analyst and being a scriptwriter had influenced on scriptwriters' perception is in line with a priory expectation but the fact that respondents' courses studied by the respondents like business administration and philosophy beats one imagination and the implication is that one do not really have to study theatre art or theatre art related courses to have a favourable disposition about soap opera usability in agricultural information management.

Table 5: Factors influencing scriptwriters' perception of soap opera usability in agricultural information management

\begin{tabular}{|c|c|c|}
\hline Factors & $\beta$-value & t-value \\
\hline Age & 3.18 & $12.05^{\star}$ \\
\hline Highest educational qualification & -0.05 & -0.26 \\
\hline Male & -0.15 & -1.14 \\
\hline Being an actor & 1.96 & $7.61^{\star \star}$ \\
\hline Being a film analyst & 2.91 & $8.49^{\star *}$ \\
\hline Being a scriptwriter & 1.41 & $5.77^{\star *}$ \\
\hline Being a director & 0.73 & $5.39^{* *}$ \\
\hline Being Married & -0.79 & $-5.40^{* *}$ \\
\hline Business administration & -0.46 & $-2.57^{\star \star}$ \\
\hline Cinematography & 0.66 & $5.55^{\star \star}$ \\
\hline Mass communication & -0.04 & -0.29 \\
\hline Education & -0.17 & -1.63 \\
\hline Philosophy & -2.14 & $-6.67^{* *}$ \\
\hline Perceived constraints & -0.02 & -0.23 \\
\hline
\end{tabular}

${ }^{*} \mathrm{P} \leq 0.05$. Source: Field survey, (2016)

\section{Conclusion and Recommendations}

Scriptwriters had high disposition to use soap opera for agricultural information dissemination, while their perceived constraints are fund-related and are on sponsorship. However, age, being married, being an actor, being a film analyst and being a scriptwriter among other factors were the major determinants of their perception of soap opera usability in agricultural information management. Therefore, scriptwriters' favourable disposition is a green light for possible production of agricultural-based soap opera hence, agricultural-based soap opera is highly recommended for agricultural information dissemination in Nigeria. However, when preparing to produce such agricultural- based soap opera, all the identified factors (age, marital status, cadre in the film industry and course of study) should be factored and incorporate into the its production as they are likely to influence writers of agricultural- based soap opera. Finally, development practitioners should seek and obtain stable and reliable sponsorship or support for sustainable use of soap opera strategy. 
Creative Commons User License: CC BY-NC-ND

Abstracted by: EBSCOhost, Electronic Journals Service (EJS), Google Scholar, Journal Seek, Scientific Commons,

Food and Agricultural Organization (FAO), CABI and Scopus
Journal of Agricultural Extension

Vol. 24 (1) January, 2020

ISSN(e): 24086851; ISSN(Print); 1119944X

http://journal.aesonnigeria.org

http://www.ajol.info/index.php/jae

Email: editorinchief@aesonnigeria.org

\section{References}

Alessandro J. and Cacilda R. (2018). Latin American telenovelas and African screen media: From reception to production. Journal of African Cultural Studies, Vol. 31(2) Pages 135-150 https://doi.org/10.1080/13696815.2018.1549829

Allen, R. C. (2014). Soap opera: Museum of broadcast communications, Chicago, IL 606545411 P: 312-245-8200.

Ali H. and Ahmadu I. (2014). Globalization, mass media and development in Nigeria: The nexus research on humanities and social sciences, Vol.4 (5), 100-101 www.iiste.org ISSN (Paper) 2224-5766 ISSN (Online) 2225-0484 (Online)

De Fossard E., Lande R. (2018): Entertainment-education for better health. INFO Reports, No. 17. Baltimore, INFO Project. Johns Hopkins Bloomberg School of Public Health. Available online at: htpp://www.infoforhealth.org/inforeports/

Kevill, S. and Connock, A. (2013). Ask the Audience: Evaluating New Ways to Fund TV Content. Report of Reuters Institute for the study of Journalism, 24-25.

https://reutersinstitute.politics.ox.ac.uk/sites/default/files/201711/Ask\%20the\%20Audie nce.pdf

Olajide B. R. and Meroyi A. A (2014) Comparative analysis of researchers', extension agents' and farmers' perception of the use of entertainment- education (EE) for agricultural information dissemination in south-western Nigeria. Journal of Agricultural Extension Vol. 18 (2) 155-163.

Oh, E. (2014).Nigeria's Film Industry: Nollywood Looks to Expand Globally. United States International Trade Commission (USITC) Executive Briefings on Trade, October 2014. (202) 205-3033 Retrieved on 31 March 2016 from

Semlali A. (2013): Fighting poverty in the Arab worldwith soap operas. Retrieved on 25th January 2015 from http://blogs.worldbank.org/arabvoices/fighting-poverty-arab-worldsoap-operas and http://www.aljazeera.com/indepth/opinion/2013/02/201322611939675778.html

Sheila T. M. and Cody M. (2015). Developing a research agenda for entertainment education and multicultural audiences. In Kirby, S. and Sarino, E. (eds.) Summary report of a conference sponsored by the Centers for Disease Control and Prevention Hollywood, Health \& Society USC Annenberg Norman Lear Center. Held at Santa Monica, California, May 21-22, 2003. 1-30.

Ullah, S., Ali, M., Nisar, M., Farid, T., Ali, I. \& Alam, S. (2014). The impacts of electronic media on academic performance of female student (2014). International Journal of Economics, Commerce and Management United Kingdom Vol. II (9), pg. 8 http://ijecm.co.uk/ ISSN 23480386 